\title{
Sindroame autoinflamatorii granulomatoase asociate cu NOD2 - o scurtă actualizare pentru clinicieni
}

\author{
Laura Damian', Mihaela Spârchez ${ }^{2,3}$, Mihaela Lupșe $e^{4,5}$, Ioana Felea', Simona Rednic ${ }^{1,6}$, \\ Cristina Pamfil ${ }^{1,6}$, Camelia Bucșa ${ }^{7}$, Romana Vulturar ${ }^{8,9}$ \\ ${ }^{1}$ Clinica de Reumatologie, Spitalul Clinic Județean de Urgență Cluj, Centrul de boli rare \\ musculo-scheletale autoimune și autoinflamatorii al SCJU Cluj (ERN-ReCONNET), Cluj-Napoca, România \\ 2Disciplina Pediatrie II, Universitatea de Medicină și Farmacie „Iuliu Hațieganu”, Cluj-Napoca, România \\ ${ }^{3}$ Clinica Pediatrie II, Spitalul Clinic Județean de Urgență pentru Copii Cluj, Cluj-Napoca, România \\ "Disciplina de Boli infecțioase, Universitatea de Medicină și Farmacie „Iuliu Hațieganu”, \\ Cluj-Napoca, România \\ ${ }^{5}$ Spitalul Clinic de Boli Infecțioase Cluj, Cluj-Napoca, România \\ ${ }^{6}$ Disciplina Reumatologie, Universitatea de Medicină și Farmacie „Iuliu Hațieganu”, Cluj-Napoca, România \\ ${ }^{7}$ Centrul de Cercetări privind Informarea asupra Medicamentului, \\ Universitatea de Medicină și Farmacie „Iuliu Hațieganu”, Cluj-Napoca, România \\ ${ }^{8}$ Departamentul de Științe Moleculare, Universitatea de Medicină și Farmacie „Iuliu Hațieganu”, \\ Cluj-Napoca, România \\ 'Laboratorul de Neuroștiințe Cognitive, Universitatea „Babeș-Bolyai“, Cluj Napoca, România
}

NOD2 (nucleotide-binding oligomerization domain-2), un receptor de recunoaștere a tiparelor moleculare, este implicat în apărarea imună înnăscută împotriva agenților patogeni, în integritatea mucoasei intestinale, compoziția microbiomului intestinal, autofagie, homeostazia imună și inflamație. Mutațiile NOD2 au fost asociate în primul rând cu boli ale copilului (sindromul Blau și sarcoidoza cu debut precoce, boala Crohn monogenică), dar și cu boli ale adultului (sindromul autoinflamator asociat NOD2 - NAID, denumit și sindrom Yao, etc.). S-au descris și forme intermediare între sindromul Blau și NAID.

Sindromul Blau și sarcoidoza cu debut precoce sunt formele familială și, respectiv, sporadică ale unei boli rare autoinflamatorii monogenice, cu transmitere autozomal dominantă. Sindromul Blau debutează în copilăria mică, evoluând cu artrită granulomatoasă fără cazeificare, cu tenosinovită proeminentă, cu o erupție maculo-papulară sau ihtioziformă cu tentă bronzată, uveită și febră intermitentă. Pot să fie prezente și o febră periodică, limfadenopatie generalizată, precum și afectare viscerală granulomatoasă. Terapia constă din corticosteroizi, terapii imunosupresoare „de fond“ și eventual terapii biologice. La adulți, sindromul NAID sau Yao evoluează cu pusee de inflamație sistemică, cu tumefierea membrelor inferioare, tenosinovită și artrită neerozivă, febră și dermatită.

Discutăm și diagnosticul diferențial cu alte boli rare granulomatoase. Creșterea informării privind aceste patologii rare autoinflamatorii, care pot să altereze calitatea vieții și să determine dizabilitate, este necesară cu scopul de a le ameliora prognosticul.

Cuvinte cheie: sindrom Blau, NAID, inflamație asociată NOD2, autoinflamație de tip granulomatos, febră periodică 


\section{INTRODUCERE}

Bolile autoinflamatorii sistemice (SAID) reprezintă un spectru de tulburări heterogene din punct de vedere clinic și genetic, care evoluează cu episoade de inflamație aparent neprovocate (1). Ultimii ani au adus o serie de noi entități patologice legate de boala autoinflamatorie granulomatoasă, în care au fost identificate mutații în gena NOD2. Caracteristicile clinice, deși orientative, nu sunt în prezent suficiente pentru a diagnostica un anumit SAID, deoarece diferite boli pot avea prezentări similare. În unele cazuri, diagnosticul corect se poate traduce printr-o mai bună gestionare a bolii. De exemplu, boala Crohn, care implică tractul digestiv, are o patogeneză incomplet înțeleasă, probabil legată de un răspuns inflamator exagerat îndreptat împotriva microorganismelor din lumenul intestinal (microbiota intestinală) (2). În ultimii ani, imaginea clinică a bolii Crohn s-a dovedit a fi legată de mai multe cauze, de la deficiența mevalonatkinazei până la bolile asociate NOD2 și altele. Unele gene asociate patologiei SAID sunt localizate pe cromozomul 16, cum ar fi gena MEFV a febrei mediteraneene familiale (FMF) și gena NOD2. Utilizarea secvențierii de ultimă generație (next generation sequencing NGS) poate identifica mai multe defecte genice implicate în inflamație, defecte care contribuie la heterogenitatea tabloului clinic (1). Dezvoltarea de noi medicamente bazate pe căile de semnalizare ar putea aduce progrese în terapia personalizată (3).

\section{NOD2}

NOD2 (nucleotide-binding oligomerization domain-containing protein 2) este o moleculă implicată în conservarea integrității barierei mucoasei intestinale și a homeostaziei imune, a autofagiei adecvate și a echilibrării compoziției microbiomului intestinal (2). NOD2 este un membru al familiei de receptori NOD-like (NLR) de recunoaștere a tiparelor (pattern-uri), care intervin în apărarea imună înnăscută împotriva agenților patogeni și a inflamației (4). NOD2 are similarități structurale moleculare cu NOD1, pirina și criopirina (3). Această proteină este exprimată în principal de limfocitele din sângele periferic și este implicată în răspunsurile imune (5). NOD2 funcționează în principal prin RICK sau RIP2 pentru a activa proteinkinazele de tip p38 activate de mitogen (MAPK) și NFkB, rezultând stimularea autofagiei și inflamației (3). Variantele NOD2 cu defecte localizate în regiunea de repetiții bogate în leucină (LRR: leucine-rich repeat) sunt asociate cu boala Crohn, în timp ce variantele cu defecte localizate în regiunea domeniului de legare a nucleotidelor (NBD), respectiv între NBD și LRR sunt asociate cu sindromul Blau și, respectiv, sindromul autoinflamator asociat cu NOD2 (NAID) (3).
Variantele NOD2 nu au fost descrise în lupusul eritematos sistemic, psoriazis sau artrita psoriazică, spondilita anchilozantă, granulomatoza cu poliangeită sau sarcoidoză la adulți (3). Anumite mutații NOD2 hiperfuncționale au fost asociate cu boala Crohn, inclusiv varianta cu debut precoce. Alte mutații au fost descrise în sindromul Blau și în sarcoidoza cu debut precoce, evoluând cu granuloame în diferite țesuturi afectate. Cea mai recentă entitate, denumită sindromul autoinflamator asociat NOD2 (NOD2-associated inflammatory diseaseNAID) sau sindromul Yao, descrisă de Yao și colab. în 2011, afectează adulții, în special femeile; au fost descrise și forme intermediare între sindromul Blau și NAID (6).

Proteina NOD2 (figura 1) este cunoscută și sub denumirea de proteina 15, care conține domeniul de recrutare al caspazei (CARD15 - caspase recruitment domain-containing protein 15) sau proteina 1 a bolii inflamatorii intestinale (IBD1 - inflammatory bowel disease protein 1), este o proteină care la om este codificată de gena NOD2 localizată pe cromozomul 16. Gena este constituită din mai mulți exoni și introni distribuiți de-a lungul a 39,5 Kb. Proteina conține 1040 aminoacizi și este un receptor citoplasmatic foarte dinamic; odată activat intracelular, sunt mediate numeroase interacțiuni și răspunsuri care includ sinteza de citokine proinflamatorii, reglarea inflamazomului, producerea de interferoni de tip I, declanșarea procesului de autofagie și alte activități de degradare cu acțiune antivirală (cum este activarea ARN-azei L cu degradarea moleculelor de ARN virale) (7).

\section{SINDROMUL BLAU ȘI SARCOIDOZA CU DEBUT PRECOCE}

Sindromul Blau (BS) și sarcoidoza cu debut precoce (early-onset sarcoidosis - EOS) sunt formele familiale și respectiv sporadice ale unei boli autoinflamatorii monogenice rare transmise autozomal dominant (8) (din acest motiv, descrierea lor va fi comună în cele ce urmează). Patogeneza bolii nu este bine înțeleasă. Sindromul Blau (și sarcoidoza cu debut precoce) sunt descrise clasic ca fiind determinate de mutații hiperfuncționale ale genei NOD2, dar pot fi, de fapt, cauzate și de mutații hipofuncționale, ca și în boala Crohn (9). Într-un studiu internațional prospectiv care a inclus 31 de pacienți cu sindrom Blau, mutațiile NOD2 observate au fost p.R334W, p.R334Q și altele (8). Majoritatea mutațiilor NOD2 descrise până în prezent sunt localizate în exonul 4 al genei $(10,11)$.

Sindromul Blau (OMIM \#186580) se caracterizează clasic prin artrită granulomatoasă, dermatită și uveită cu debut în copilăria mică (10). Semnul său clinic sugestiv este prezența unei erupții cutanate „bronzate“, maculo-papulare sau scuamoase, une- 


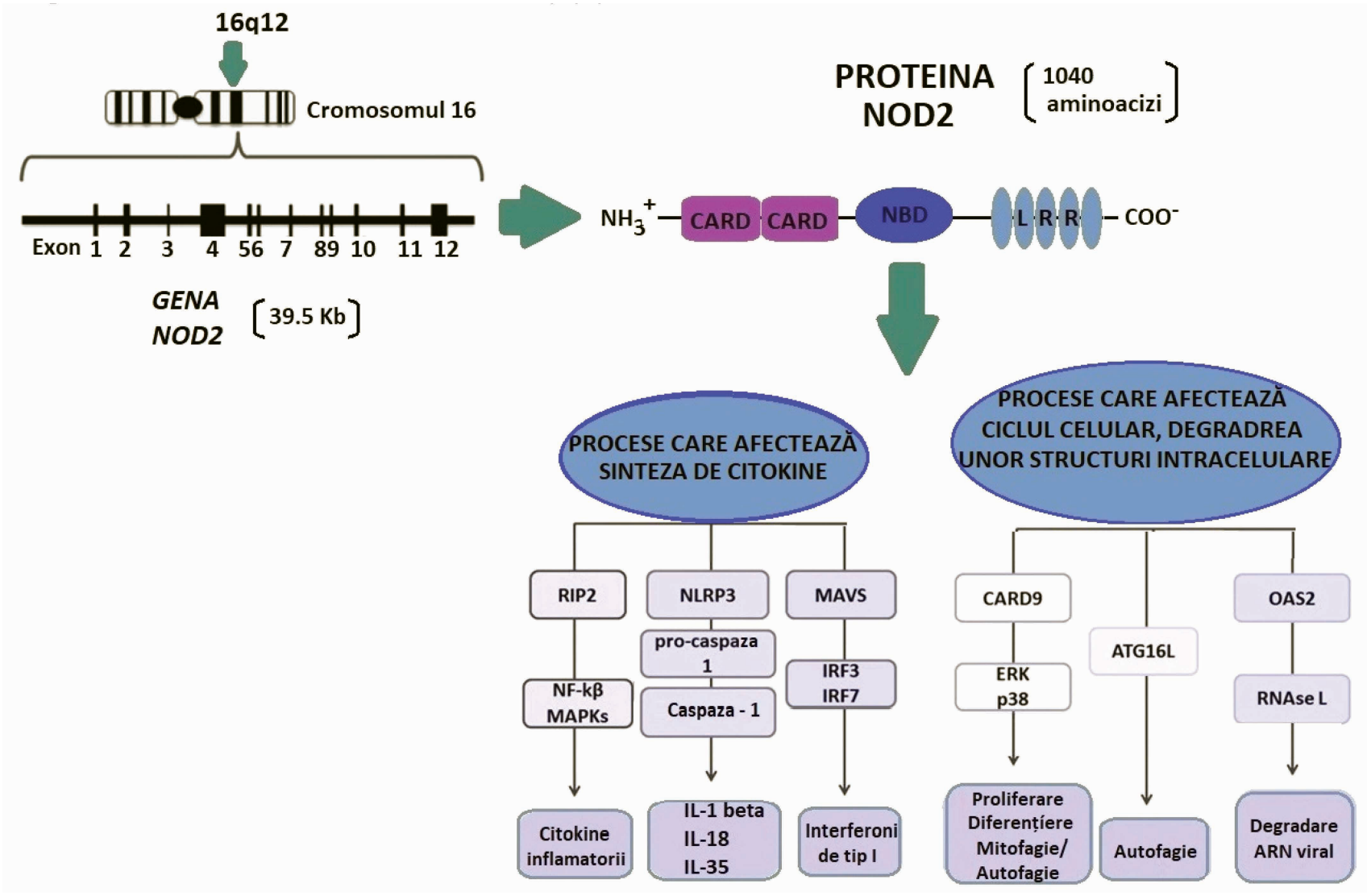

FIGURA 1. Reprezentarea genei și proteinei NOD2 cu tipurile de procese celulare declanșate de activarea sa, relevante pentru răspunsurile imune $(1,7)$. LRR - regiunea leucine-rich repeat (repetiții bogate în leucină); RIP2 - receptor-interacting protein 2 (proteina 2 care interacționează cu receptorul); ERK - extracellular signal-regulated kinase (kinaza extracelulară controlată de semnal); ATG16L1 - autophagy-related 16-like 1 protein complex (complexul proteinei 1 legate de autofagie); IRF3, IRF7 - factorii 3 și 7 de reglare ai interferonului; MAPK - mitogen-activated protein kinase (proteina kinază activată de mitogen); MAVS - mitochondrial antiviral-signaling protein (proteină de semnalizare antivirală mitocondrială), NF-kB - factor nuclear кB, OAS2: 2'-5'-oligoadenylate synthetase type 2 (2'-5'-oligoadenilat sintetaza tip 2).

ori ihtioziforme. Se pot adăuga tabloului clinic și pusee de febră.

Descrise clasic ca mutații NOD2 cu câștig de funcție, BS / EOS pot fi, de fapt, cauzate de mutații cu pierderea funcției, asemănătoare cu boala Crohn (9).

Artrita din sindromul Blau este simetrică, cel mai adesea poliarticulară, deși au fost descrise și forme oligoarticulare. Artrita afectează mai ales articulațiile radiocarpiene, gleznele, genunchii și articulațiile interfalangiene proximale, iar pacienții cu sindrom Blau pot prezenta în continuare artrită activă peste 10 ani (8). Tenosinovita proeminentă, flască, cu consistență palpatorie semifluidă, este foarte sugestivă pentru această boală. Pot fi prezente, de asemenea, camptodactilia și contractura interfalangiană proximală. Aparent, scheletul axial și articulațiile temporo-mandibulare nu sunt afectate (4).

Radiografia de mâini relevă în general o artrită neerozivă, cu osteopenie periarticulară difuză; pot fi prezente, totuși, și îngustări de spații articulare și displazia scafoidului și semilunarului, cu rotație și pseudocolaps al osului semilunar și scafoid, precum și un aspect particular, alungit și îngustat, al diafizei metacarpianului II (8). La adulții cu sindrom Blau, se descrie un aspect radiologic caracteristic al mâinii: epifiza radială sau cubitală biconcavă și scurtarea ulnei, cu un aspect hipertrofic al epifizei distale ulnare (8). Absența supracreșterii epifizare poate diferenția artrita din sindrom Blau de cea din artrita juvenilă idiopatică poliarticulară (8). Modificări osoase displazice observate la $2 / 3$ dintre pacienții cu sindrom Blau sugerează implicarea NOD2 în morfogeneza osoasă (8).

Boala oculară este frecventă, cu uveita granulomatoasă și inflamație a corpului vitros în $2 / 3$ dintre cazuri, determinând pierderea vederii la 1/3 dintre cazuri; din acest motiv, trebuie căutată și identificată proactiv (8). Uveita din sindromul Blau este o panuveită progresivă cu coroidită multifocală (12). Afectarea cutanată mai sus-descrisă, în afara aspec- 
tului tipic de erupție maculo-papulară eritematoasă cu tentă „bronzată“, uneori solzoasă, pe trunchi și extremități, poate fi uneori foarte discretă, doar cu hiperpigmentare regională, și este adesea confundată cu dermatita atopică (4). Febra periodică, limfadenopatia generalizată, hepatosplenomegalia și hepatita granulomatoasă sunt relativ frecvente. De asemenea, se descriu alte modificări granulomatoase renale (cu nefrită interstițială, nefrocalcinoză sau hipertensiune), cardiace, vasculare (vasculita leucocitoclastică sau de vase mari, asemănătoare bolii Takayasu) și manifestări neurologice (neuropatii craniene sau periferice) $(8,13)$. Alte manifestări pot include eritemul nodos și sialadenita, ca în sarcoidoza adultului, însă, spre deosebire de aceasta, afectarea pulmonară nu este frecventă (8). Pneumopatia interstițială a fost, totuși, observată la o minoritate de pacienți urmăriți prospectiv, iar întrun caz a fost observat trombembolism pulmonar (8).

$\mathrm{Nu}$ există un tratament standardizat pentru sindromul Blau (9). Se administrează corticoterapie, terapii imunosupresoare „de fond“ și eventual biologice (anti-TNF, anti-IL-1 etc.) în cazurile refractare $(8,14)$. Dintre acestea din urmă, tratamentul antiTNF (infliximab, adalimumab sau etanercept) a fost cel mai frecvent utilizat, cu controlul parțial al bolii articulare și al uveitei (8). Canakinumab a fost utilizat cu succes la un caz de sindrom Blau cu uveită refractară (15).

\section{BOALA AUTOINFLAMATORIE ASOCIATĂ CU NOD2 (SINDROMUL YAO)}

Boala autoinflamatorie asociată cu NOD2 (sindromul Yao sau NAID, OMIM \#617321) este o boală multisistemică, genetică complexă, care evoluează cu febră periodică, artrită inflamatorie, tenosinovită „flască”, afectând în principal membrele inferioare, și dermatită (1). Incidența estimată este de 1-10 cazuri/100.000 persoane (16). Boala afectează în principal adulții caucazieni, într-un raport femei: bărbați de 2:1 (17), însă s-a raportat o posibilă coexistență a NAID cu sindromul Blau și la un copil (18).

Un puseu inflamator poate dura zile până la săptămâni, cu intervale asimptomatice de câteva săptămâni sau luni între pusee. Artralgia, oligo-sau poliartrita apar periodic, sunt frecvente, neerozive și în mod caracteristic asociate $\mathrm{cu}$ tumefierea extremitătilor inferioare; între episoadele acute, articulațiile pot părea normale. Cu toate acestea, un sfert dintre pacienți pot dezvolta tumefieri intermitente unilaterale sau bilaterale ale membrelor inferioare. Alte manifestări clinice sunt sindromul sicca-like și afectarea gastro-intestinală (3). Unele cazuri evoluează cu crize recurente de febră mare, dureri abdominale, diaree, vărsături și macule eritematoase nepruriginoase, apărute pe față și trunchi (19). Au fost raportate rareori pneumonite granulomatoase, pleurită, pericardită sau miozită oculară $(20,21)$.

Diagnosticul diferențial al NAID este vast, intrând în discuție mai ales sindromul Blau, boala Crohn sau alte SAID. De interes, episoadele paroxistice de inflamație, cu febră și diaree, în NAID pot imita o tulburare mastocitară sau o tumoră neuroendocrină, dar peptidul intestinal vasoactiv VIP cu valori crescute într-un caz de NAID sugerează mecanisme comune (22).

În timpul unui episod inflamator, testele de laborator pot să releve un sindrom inflamator nespecific (leucocitoză cu neutrofilie, anemie). Pot apărea tranzitor titruri mici de anticorpi antinucleari (19). Biopsia cutanată prezintă o dermatită granulomatoasă cu multe histiocite sau o dermatită spongiotică (23).

Într-o cohortă mare, de 143 de pacienți adulți (majoritatea caucazieni, predominant de sex feminin) cu un fenotip clinic sugestiv pentru NAID, aproape jumătate dintre aceștia (67) purtau variante NOD2, iar 81\% dintre acești purtători (54 din 67) aveau NAID, care a fost sporadică în aproape toate cazurile. Profilul genetic, distinct de boala Crohn, prezenta variante bialelice NOD2 tip IVS9 $(+158)$ sau de tip heterozigot compus IVS8 (+158) și R702W.

Expresia NOD2 și activarea căii NOD2 sunt aberante în NAID, iar genotipurile specifice NOD2 au ca rezultat expresia distinctă a NOD2 și, în consecință, a citokinelor (17). NOD2 disfuncțional în NAID pare mai degrabă un amplificator sau modificator al inflamației, în anumite condiții, și nu neapărat un inițiator al inflamației (17).

Terapia în NAID constă în administrarea de glucocorticoizi (baza terapiei în timpul puseelor inflamatorii) și sulfasalazine. Cu toate acestea, aproximativ jumătate dintre pacienți au atacuri frecvente de boală. Terapiile biologice, de exemplu anti-TNF, anti-IL-6 sau anti-IL1, pot fi benefice în cazurile refractare $(16,17,24)$.

\section{BOALA CROHN ASOCIATĂ MUTAȚIILOR NOD2}

Mutațiile NOD2 au fost asociate bolii Crohn, iar transmiterea recesivă a alelelor NOD2 explică 10\% dintre cazurile de boală Crohn la adulți, majoritatea cu debut precoce (25). Cele trei polimorfisme principale NOD2/CARD15 asociate bolii Crohn sunt $\mathrm{p}$. R702W, p.G908R și p.L1007fs (26). Purtătorii mai multor alele NOD2 de risc au o susceptibilitate crescută la boala Crohn, pe când variantele NOD2 rare și variante bialelice cu frecvență mică au fost găsite la aproximativ 8\% dintre pacienți într-o cohortă de boală Crohn pediatrică (25). Pacienții pediatrici cu 
boală Crohn au, în general, o formă mai severă de boală decât cea debutată la vârstă înaintată, cu afectarea tractului gastro-intestinal superior, a intestinului subțire și a țesuturilor perianale (25). Mai mult, prevalența complicațiilor, cum ar fi densitatea minerală osoasă scăzută, este crescută în boala Crohn cu debut precoce (26).

\section{ALTE BOLI ASOCIATE CU NOD2 SAU CU CALEA NOD2}

Camptodactilia familială asociată cu boala granulomatoasă a fost propusă ca formă intermediară a bolilor asociate cu NOD2 (6). De remarcat că pacientele, două femei caucaziene în vârstă de 50 de ani, cu artrită inflamatorie și cu antecedente familiale de camptodactilie, aveau variantele NOD2 IVS8 (+158) și respectiv R703C, iar clinic - granuloame cu necroză fără cazeificare, fie localizate mediastinal, fie periarticular subcutanat; una dintre paciente avea creșterea în volum a glandei parotide și febră (6). Aceste caracteristici clinice sugerează că boala granulomatoasă asociată cu variantele NOD2 ar putea reprezenta o formă intermediară între Blau și NAID (6).

Interesant, deși NOD2 pare să nu fie implicat în sarcoidoza adultului (3), mutațiile altor gene ale căii NOD2 (TAB1, TAB2, MAPK-13) au fost decelate în cazuri de sarcoidoză la adulți cu manifestări clinice de sindrom Blau (26). Prin urmare, mutațiile „din aval“ ale căii NOD2 ar putea juca un rol în inflamația granulomatoasă comună sindromului Blau și sarcoidozei (27).

O cantitate crescută de ARNm corespunzător genei NOD2 s-a identificat în boala Behçet (28) și în sindromul Vogt-Koyanagi-Harada, o boală rară granulomatoasă inflamatorie cu afectare oculară și de sistem nervos central (29). Creșterea expresiei NOD2 a fost observată în artrita reumatoidă, în bolile cardiovasculare, în obezitate și în sindromul metabolic $(30,31)$. Și în dermatita atopică s-au raportat polimorfisme NOD2 (32).

De asemenea, variante NOD2, printre altele, au fost asociate cu cariile dentare și cu parodontita agresivă care apare la vârstă foarte tinere $(5,31)$.

Polimorfisme NOD2 (în special cele mai frecvente R702W, G908R și 3020insC) au fost identificate în diferite tipuri de cancer (gastric, colorectal, ovarian, mamar, prostatic, testicular, pulmonar, renal, de vezică urinară, piele, în tumori endocrine nontiroidiene, limfom și leucemie) $(31,33)$.

\section{ALTE BOLI RARE MONOGENICE GRANULOMATOASE}

Alte boli monogenice cu manifestări autoinflamatorii, autoimune și, eventual, de imunodeficiență, pot avea prezentări similare cu cele ale bolilor autoinflamatorii asociate NOD2 (34). De exemplu, mutațiile patogene ale genei PLCG2 care codifică fosfolipaza C (PLC2), o enzimă exprimată în celulele hematopoietice, determină două boli, ambele transmise autozomal dominant: PLAID și APLAID. PLAID (PLCG2-associated antibody deficiency and immune dysregulation) se caracterizează prin apariția de granuloame cutanate (pe față, nas, degete etc.), urticarie indusă de frig, uneori cu vezicule și diverse manifestări autoimune și de imunodeficiență (34). APLAID (autoinflamation-PLCy2-associated antibody deficiency-immune deficiency) apare în copilărie, evoluând cu febră, vezicule sau rash cutanate induse de căldură sau transpirație, inflamație oculară, enterocolită, artralgii și boală pulmonară interstițială progresivă $(35,36)$. În PLAID și APLAID, administrarea imunoglobulinelor poate fi necesară pentru imunodeficiență, în timp ce inflamația este dificil de tratat la ora actuală, deoarece nu răspunde la anti-IL-1 sau la alți inhibitori ai citokinelor, sugerând implicarea unor căi patogene încă nedescrise (34).

Gena LACC1 codifică proteina FAMIN (fatty acid metabolism and immunity nexus), având omologii cu oxidoreductazele bacteriene cu multipli ioni de cupru (34). Proteina FAMIN, exprimată în macrofage, controlează oxidarea lipidelor și lipogeneza. LACC1 este implicată în eliminarea agenților patogeni și în boala granulomatoasă, similar cu NOD2 (34). Mutațiile LACC1 au fost asociate cu boala Crohn cu debut precoce, cu artrita idiopatică juvenilă sistemică și cu lepra diseminată, implicând intervenția factorilor de mediu, în special a microbiomului, în expresia bolii (34). De asemenea, studiul fenotipurilor asociate cu mutațiile NOD2 și LACC1 subliniază rolul factorilor de mediu în modularea tabloului clinic și în boli mai frecvente, cum ar fi sarcoidoza (9).

Granuloamele diseminate pot apărea și în boala granulomatoasă cronică, un deficit imun primar rar, cauzat de mutații ale genelor NADPH-oxidazelor fagocitare (CYBB, CYBA, NCF1, NCF2 și NCF4). Boala se caracterizează prin infecții bacteriene și fungice recurente, ale pielii, ganglionilor limfatici, plămânilor, ficatului, rinichilor, oaselor și creierului, infecții severe, care pun viața în pericol (37). Inflamația excesivă, inclusiv colita și abcesele perirectale care imită boala Crohn, poate apărea în paralel cu acest deficit imun. La acest tablou clinic se pot adăuga artrita, uveita, glomerulonefrita sau lupusul. Diagnosticul se face prin măsurarea activității oxidazei NADPH, de exemplu cu testul nitroblue tetrazolium (NBT). Testarea genetică, inclusiv pentru deficitul glucozo-6 fosfat dehidrogenazei - G6PD - și mutația genelor Rac2 (care duc la tablouri clinice similare), trebuie efectuată ori de câte ori este posibil (38). Nu există terapie standardizată. În afară de 
terapia promptă a infecțiilor, se iau în considerare interferonul uman recombinant, utilizarea cu prudență a medicației anti-TNF în colita severă, a corticosteroizilor în inflamația obstructivă, trans-

Testarea genetică poate să releve combinații ale mai multor gene, explicând fenotipuri anume sau predispoziția spre anumite complicații. De exemplu, coexistența unei sarcoidoze cu debut precoce și a unei deficiențe parțiale de receptor 1 al interferonului y (determinată de defecte ale IFNyR1) a determinat o infecție micobacteriană indusă de vaccinarea BCG și semne de sindrom de activare macrofagică după inițierea terapiei antituberculoase (39). plantul de măduvă osoasă și terapia genică (37).

\section{CONCLUZII}

Bolile granulomatoase autoinflamatorii asociate NOD2 sunt un grup de tulburări în expansiune, cu trăsături distincte. Identificarea acestora poate ajuta la caracterizarea mai bună a fenotipului clinic la diferite populații și grupe de vârstă și, de asemenea, la îmbunătățirea abordării terapeutice. Datele moleculare sunt cruciale pentru a îțtelege mai bine boala și gestionarea acesteia și pentru a îmbunătăți prognosticul pacienților.

\section{Multumiri}

Toți autorii au contribuții egale.

Autorii mulțumesc Cristinei Vulturar pentru sprijinul oferit în redactarea manuscrisului.

\section{Conflict of interest: none declared Financial support: none declared}

\section{BIBLIOGRAFIE}

1. Yao Q, Li E, Shen B. Autoinflammatory disease with focus on NOD2-associated disease in the era of genomic medicine. Autoimmunity. 2019;52(2):48-56.

2. De Bruyn M, Vermeire S. NOD2 and bacterial recognition as therapeutic targets for Crohn's disease. Expert Opin Ther Targets. 2017;21(12):1123-39.

3. Yao Q. Nucleotide-binding oligomerization domain containing 2: structure, function, and diseases. Semin Arthritis Rheum. 2013;43(1):125-30.

4. Wouters CH, Maes A, Foley KP, Bertin J, Rose CD. Blau syndrome, the prototypic auto-inflammatory granulomatous disease. Pediatr Rheumatol Online J. 2014;12:33.

5. Mizuno N, Kume K, Nagatani Y, et al. Aggressive periodontitis and NOD2 variants. J Hum Genet. 2020;65(10):841-46.

6. Shen M, Moran R, Tomecki KJ, et al. Granulomatous disease associated with NOD2 sequence variants and familial camptodactyly: An intermediate form of NOD2-associated diseases?. Semin Arthritis Rheum. 2015;45(3):357-60.

7. Domínguez-Martínez DA, Núñez-Avellaneda D, Castañón-Sánchez CA, Salazar MI. NOD2: Activation During Bacterial and Viral Infections, Polymorphisms and Potential as Therapeutic Target. Rev Invest Clin. 2018;70(1):18-28.

8. Rosé CD, Pans S, Casteels I, et al. Blau syndrome: cross-sectional data from a multicentre study of clinical, radiological and functional outcomes. Rheumatology (Oxford). 2015;54(6):1008-1016.

9. Szymanski AM, Ombrello MJ. Using genes to triangulate the pathophysiology of granulomatous autoinflammatory disease: NOD2, PLCG2 and LACC1. Int Immunol. 2018;30(5):205-13.

10. Mensa-Vilaro A, Cham WT, Tang SP, et al. Brief Report: First Identification of Intrafamilial Recurrence of Blau Syndrome due to Gonosomal NOD2 Mosaicism. Arthritis Rheumatol. 2016; 68(4):1039-44.

11. International Society for Systemic Autoinflammatory Fevers. Infevers: database for hereditary autoinflammatory disorders mutations. Available at: http://fmf.igh.cnrs.fr/ISSAID/infevers.

12. Sarens IL, Casteels I, Anton J, et al. Blau syndrome-associated uveitis: preliminary results from an international prospective interventional case series. Am J Ophtalm. 2018;187:158-66.

13. Meiorin SM, Espada G, Costa CE, et al. Granulomatous nephritis associated with R334Q mutation in NOD2. J Rheumatol. 2007;34(9):1945-47.

14. Simonini $G, X u Z$ Z, Caputo $R$, et al. Clinical and transcriptional response to the long-acting interleukin-1 blocker canakinumab in Blau syndrome-related uveitis. Arthritis Rheum. 2013;65(2):513-8.
15. Chen J, Luo Y, Zhao M, Wu D, Yang Y, Zhang W, Shen M. Effective treatment of TNF $\alpha$ inhibitors in Chinese patients with Blau syndrome. Arthritis Res Ther. 2019;12;21(1):236.

16. Yao $Q$, Shen B. A systematic analysis of treatment and outcomes of NOD2-associated autoinflammatory diseas. Am J Med. 2017;130(3):365 e13-e18.

17. McDonald C, Shen M, Johnson EE, et al. Alterations in nucleotidebinding oligomerization domain 2- expression, pathway activation, and cytokine production in Yao syndrome. Autoimmunity. 2018; 51(2):53-61.

18. Dziedzic M, Marjańska A, Bąbol-Pokora K, et al. Co-existence of Blau syndrome and NAID? Diagnostic challenges associated with presence of multiple pathogenic variants in NOD2 gene: a case report. Pediatr Rheumatol Online J. 2017;15(1):57.

19. Gorevic P, Yao Q. Yao syndrome: a case report \& clinical review. The Rheumatologist, 2020. Available at: https://www.the-rheumatologist. org/article/yao-syndrome-a-case-report-clinical-review.

20. Yao Q, Piliang M, Nicolacakis K, et al. Granulomatous pneumonitis associated with adult-onset blau-like syndrome. American Journal of Respiratory and Critical Care Medicine. 2012;186(5):465-6.

21. Caso F, Gallozzi P, Costa L, et al. Autoinflammatory granulomatous diseases: from Blau syndrome and early-onset sarcoidosis to NOD-2 mediated disease and Crohn's disease. RMD Open. 2015;1(1):e000097.

22. Navetta-Modrov B, Ghebrehiwet B, Yao Q. Yao syndrome: A potential role and association of vasoactive intestinal peptide with NOD2. Rheumatology and Immunology Research. 2021;2(1):57-9.

23. Yao $Q$, Shen M, McDonald C, et al. NOD2-associated autoinflammatory disease: a large cohort study. Rheumatology (Oxford). 2015;54(10):1904-12.

24. Yao Q. Therapeutic Value of Canakinumab in Patients with Yao Syndrome. Arthritis Rheumatol. 2018;70 (suppl 10).

25. Horowitz JE, Warner N, Staples J, et al. Mutation spectrum of NOD2 reveals recessive inheritance as a main driver of early onset Crohn's disease. Sci Rep. 2021;11(1):5595. of NOD2 gene variants on disease behaviour and treatment in Crohn's disease. BMC Gastroenterol. 2013;13:77.

27. Bello GA, Adrianto I, Dumancas GG, et al. Role of NOD2 Pathway Genes in Sarcoidosis Cases with Clinical Characteristics of Blau Syndrome. Am J Respir Crit Care Med. 2015;192(9):1133-35.

28. Hamzaoui K, Abid H, Berraies A, et al. NOD2 is highly expressed in Behçet disease with pulmonary manifestations. J Inflamm (Lond). 2012;9(1):3
26. Posovszky C, Pfalzer V, Lahr G, et al. Age-of-onset-dependent influence 
29. Deng B, Ye Z, Li L, et al. Higher Expression of NOD1 and NOD2 is Associated with Vogt-Koyanagi-Harada (VKH) Syndrome But Not Behçet's Disease (BD). Curr Mol Med. 2016;16(4):424-435.

30. Kim HW, Kwon YJ, Park BW, et al. Diferential expression of NOD2-like receptors and their association $s$ with inflammatory responses in rheumatoid arthritis. Clin Exp Rheumatol. 2017;35(4):630-7.

31. Negroni A, Piedomenico M, Cucciara S, et al. NOD2 and inflammation: current insights. J Inflamm Res. 2018;11:49-60.

32. Macaluso F, Nothnagel M, Parwez Q, et al. Polymorphisms in NACHT-LRR (NLR) genes in atopic dermatitis. Experimental Dermatology. 2007;16:692-8.

33. Kutikhin AG. Role of NOD1/CARD4 and NOD2/CARD15 gene polymorphisms in cancer etiology. Human Immunology. 2011;72(10):955-68.

34. Beck DB, Aksentijevich I. Biochemistry of Autoinflammatory Diseases: Catalyzing Monogenic Disease. Front Immunol. 2019;10:101.
35. Zhou Q, Lee GS, Brady J, et al. A hypermorphic missense mutation in PLCG2, encoding phospholipase Cy2, causes a dominantly inherited autoinflammatory disease with immunodeficiency. Am J Hum Genet. 2012;91(4):713-20

36. Aderibigbe OM, Priel DL, Lee CC, et al. Distinct Cutaneous Manifestations and Cold-Induced Leukocyte Activation Associated With PLCG2 Mutations. JAMA Dermatol. 2015;151(6):627-634.

37. Roos D. Chronic granulomatous disease. Br Med Bull. 2016; 118(1):50-63.

38. Papa R, Penco F, Volpi S, et al. Actin remodeling defects leading to autoinflammation and immune dystregulation. Front Immunol. 2021;11:604206

39. Cakan M, Kesindemirci G, Aydogmus C, et al. Coexistence of early onset sarcoidosis and partial interferon-y receptor 1 deficiency. Turkish J Ped. 2016;58:545-9. 